\title{
Flavobacterium croceum sp. nov., isolated from activated sludge
}

\author{
Minjeong Park, ${ }^{1}$ Shipeng Lu, ${ }^{1}$ Seung Hyun Ryu, ${ }^{1}$ Bok Sil Chung, ${ }^{1}$ \\ Woojun Park, ${ }^{2}$ Chang-Jin $\mathrm{Kim}^{3}$ and Che Ok Jeon ${ }^{1}$ \\ ${ }^{1}$ Division of Applied Life Science, EB-NCRC, PMBBRC, Gyeongsang National University, Jinju \\ 660-701, Republic of Korea \\ ${ }^{2}$ Division of Environmental Science and Ecological Engineering, Korea University, Seoul \\ 136-701, Republic of Korea \\ ${ }^{3}$ Korea Research Institute of Bioscience and Biotechnology, 52 Oeundong, Yusong, Daejeon \\ 305-333, Republic of Korea
}

Correspondence

Che Ok Jeon

cojeon@gsnu.ac.kr

\begin{abstract}
A Gram-negative, non-motile, rod-shaped bacterium, designated strain EMB $47^{\top}$, was isolated from activated sludge performing enhanced biological phosphorus removal in a sequencing batch reactor. Growth was observed between 10 and $40^{\circ} \mathrm{C}$ (optimum, $25-35^{\circ} \mathrm{C}$ ) and between pH 5.0 and 8.5 (optimum, $\mathrm{pH} 7 \cdot 5-8 \cdot 0$ ). The predominant fatty acids of strain $\mathrm{EMB}^{\mathrm{N}} 7^{\top}$ were iso- $\mathrm{C}_{16: 0}$ $3-\mathrm{OH}$, iso- $\mathrm{C}_{15: 1} \mathrm{G}, \mathrm{C}_{15: 0}$, iso- $\mathrm{C}_{15: 0}$, iso- $\mathrm{C}_{14: 0}$ and iso- $\mathrm{C}_{16: 0}$ and it contained phosphatidylethanolamine, diphosphatidylglycerol and phosphatidylcholine as polar lipids. The $\mathrm{G}+\mathrm{C}$ content of the genomic DNA was $40 \cdot 8 \mathrm{~mol} \%$ and the major quinone was MK-6. Comparative 16S rRNA gene sequence analyses showed that strain EMB $47^{\top}$ formed a distinct phyletic line within the genus Flavobacterium. The levels of $16 \mathrm{~S}$ rRNA gene sequence similarity with respect to Flavobacterium species were below $94 \cdot 7 \%$. On the basis of the phenotypic, chemotaxonomic and molecular data, strain EMB $47^{\top}$ represents a novel species within the genus Flavobacterium, for which the name Flavobacterium croceum sp. nov. is proposed. The type strain is EMB $47^{\top}(=\mathrm{KCTC}$ $12611^{\top}=$ DSM $17960^{\top}$ ).
\end{abstract}

Since the genus Flavobacterium, belonging to the phylum Bacteroidetes (formerly the Cytophaga-FlavobacteriumBacteroides group), was emended (Bernardet et al., 1996), several novel Flavobacterium species have been described: these have been isolated from diverse habitats such as micromats, fresh water, seawater, Antarctic lakes, soil, the gut of an earthworm and from sediments (McCammon \& Bowman, 2000; Van Trappen et al., 2002, 2004; Zhu et al., 2003; Horn et al., 2005). The physiological characteristics of members of the genus Flavobacterium are also diverse: they can be psychrophilic, psychrotolerant or mesophilic; they can be halotolerant, halophilic or sensitive to salts; and they produce a variety of enzymes (Humphry et al., 2001; Tamaki et al., 2003; Aslam et al., 2005). These findings suggest that the genus Flavobacterium may have important environmental roles. Activated-sludge processes with cyclic changes of anaerobic and aerobic conditions have been used to remove phosphate from wastewater and are increasingly used to reduce the eutrophication process in lakes (Mino

The GenBank/EMBL/DDBJ accession number for the $16 \mathrm{~S}$ rRNA gene sequence of strain EMB47 ${ }^{\top}$ is DQ372982.

A transmission electron micrograph showing the general morphology of strain EMB $47^{\top}$ is available as a supplementary figure in IJSEM Online. et al., 1987; Jeon \& Park, 2000). An insight into the bacterial community responsible for phosphorus removal is a prerequisite for understanding and controlling the enhanced biological phosphorus removal mechanism and its processes. Therefore, efforts have been made in our laboratory to isolate and characterize members of the bacterial community found in activated sludge that perform enhanced biological phosphorus removal. Here we describe the taxonomic characterization of a novel species belonging to the genus Flavobacterium.

Strain EMB $47^{\mathrm{T}}$ was isolated from activated sludge that was performing enhanced biological phosphorus removal in a laboratory-scale sequencing batch reactor. Sodium acetate was supplied as a sole carbon source, and the operation of the sequencing batch reactor was as described elsewhere (Jeon et al., 2003). The sludge sample was diluted serially with $1 \%(\mathrm{w} / \mathrm{v})$ saline solution and spread on R2A agar (Difco) maintained at $20{ }^{\circ} \mathrm{C}$ for 5 days. Subcultivation was performed on $\mathrm{R} 2 \mathrm{~A}$ agar maintained at $30^{\circ} \mathrm{C}$ for 3 days.

Sequencing of the $16 \mathrm{~S}$ rRNA gene was carried out as described previously (Lane, 1991). The resulting 16S rRNA gene sequence $\left(1439 \mathrm{nt}\right.$ ) of strain $\mathrm{EMB} 47^{\mathrm{T}}$ was compared with 16S rRNA gene sequences available from GenBank, 
using the BLAST program (http://www.ncbi.nlm.nih.gov/ blast/) to determine an approximate phylogenetic affiliation; gene sequences were aligned with those of closely related species by using CLUSTAL $\mathrm{W}$ software (Thompson et al., 1994). Phylogenetic trees were constructed by using three different methods, namely the neighbour-joining, maximum-likelihood and maximum-parsimony algorithms available in PHYLIP, version 3.6 (Felsenstein, 2002). Values for sequence similarity between the novel strain and other related members of the genus Flavobacterium were computed using Similarity Matrix, version 1.1 (Ribosomal Database Project II; http://35.8.164.52/html/; Cole et al., 2003). A bootstrap analysis was performed according to the algorithm of the Kimura two-parameter model (Kimura, 1980) of the neighbour-joining method in the PHYLIP software package. A phylogenetic analysis based on the $16 \mathrm{~S}$ rRNA gene sequences indicated that strain EMB47 ${ }^{\mathrm{T}}$ formed a phyletic lineage with Flavobacterium columnare IAM $14301^{\mathrm{T}}$ and Flavobacterium saliperosum AS $1.3801^{\mathrm{T}}$ within the genus Flavobacterium, supported by a high bootstrap value (99.0\%) (Fig. 1). The overall topology of the neighbour-joining tree was supported by those of the trees constructed using the maximum-likelihood and maximum-parsimony algorithms (data not shown). Comparative $16 \mathrm{~S}$ rRNA gene sequence analyses showed that the novel isolate was most closely related to Flavobacterium aquatile ATCC $11947^{\mathrm{T}}$, F. saliperosum AS $1.3801^{\mathrm{T}}$ and $F$. columnare IAM $14301^{\mathrm{T}}$, with similarities of $94 \cdot 2,93 \cdot 9$ and $92 \cdot 6 \%$, respectively.

Gram staining was performed using a bioMérieux Gram stain kit according to the manufacturer's instructions. Cell morphology, flagella and gliding motility were studied using phase-contrast microscopy and transmission electron microscopy (JEM-1010; JEOL) as described previously (Bernardet et al., 2002; Jeon et al., 2005). The physiological characteristics of strain $\mathrm{EMB} 47^{\mathrm{T}}$ were examined by growing the isolate on R2A medium at different temperatures and $\mathrm{pH}$ values. R2A media with different $\mathrm{pH}$ values were prepared as described previously (Gomori, 1955). Salt tolerance was tested on R2A media supplemented with $0-3 \%(\mathrm{w} / \mathrm{v}) \mathrm{NaCl}$ for 5 days at $30^{\circ} \mathrm{C}$. Duplicate antibioticsusceptibility tests were performed using filter-paper discs (diameter, $8 \mathrm{~mm}$ ) containing ampicillin $(10 \mu \mathrm{g})$, polymyxin B (100 U), streptomycin $(50 \mu \mathrm{g})$, penicillin G (10 IU), chloramphenicol $(100 \mu \mathrm{g})$, gentamicin $(30 \mu \mathrm{g})$, tetracycline $(30 \mu \mathrm{g})$, kanamycin $(30 \mu \mathrm{g})$, lincomycin $(15 \mu \mathrm{g})$, oleandomycin $(15 \mu \mathrm{g})$, neomycin $(30 \mu \mathrm{g})$, carbenicillin $(100 \mu \mathrm{g})$ or novobiocin $(50 \mu \mathrm{g})$. Oxidase activity was tested by means of the oxidation of $1 \%(\mathrm{w} / \mathrm{v})$ tetramethyl-p-phenylenediamine (Merck). Catalase activity was evaluated by monitoring the production of oxygen bubbles in $3 \%(\mathrm{v} / \mathrm{v})$ aqueous hydrogen peroxide solution. The production of flexirubintype pigments and extracellular glycans was investigated using the $\mathrm{KOH}$ and Congo red tests, respectively, following the minimal standards for the Flavobacteriaceae (Bernardet et al., 2002). The hydrolysis of casein, gelatin, hypoxanthine, Tweens 80 and 20, aesculin, urea, tyrosine, starch, carboxymethylcellulose and xanthine was investigated after 7 days incubation on R2A agar, according to previously described methods (Lanyi, 1987; Gerhardt et al., 1994). Nitrate reduction was determined according to the method of Lanyi (1987), and acid production from carbohydrates was tested for as described by Leifson (1963). Additional

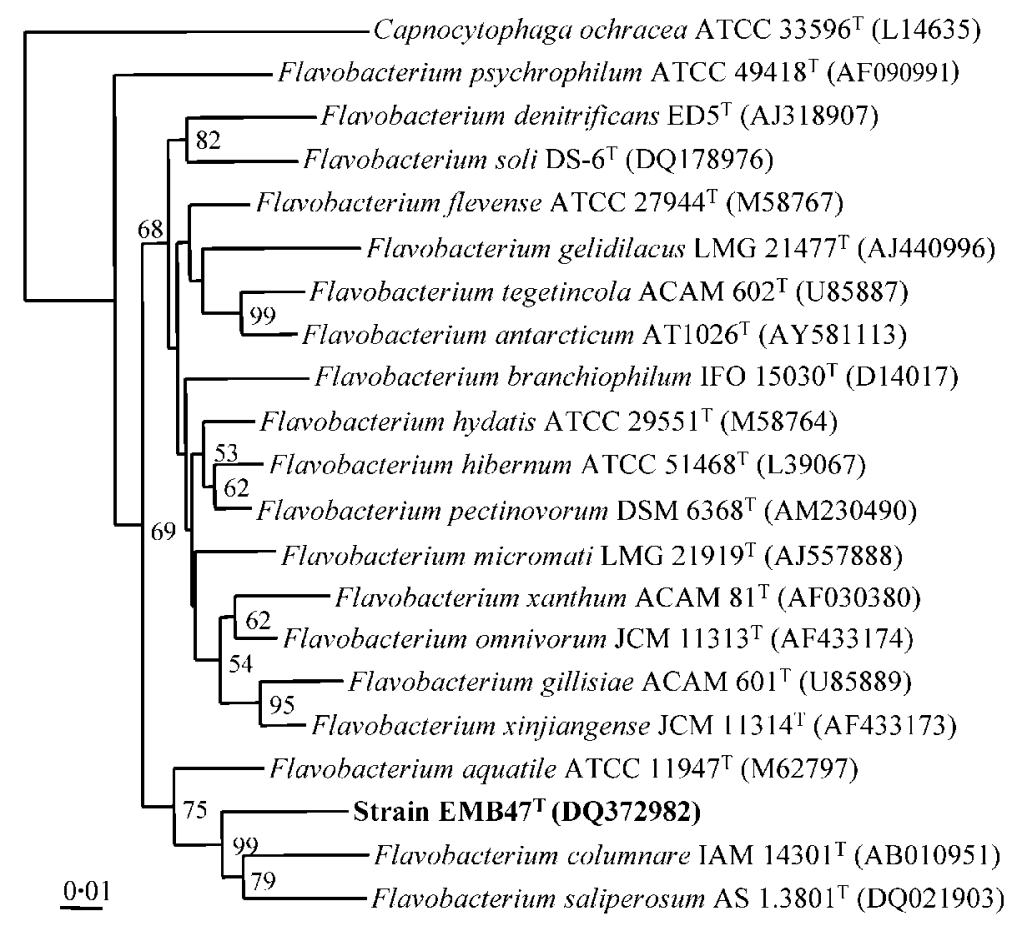

Fig. 1. Neighbour-joining phylogenetic tree, based on 16S rRNA gene sequences, showing the relationships of strain EMB47 $7^{\top}$ and related taxa. Bootstrap values are expressed as percentages of 1000 replicates; only values greater than $50 \%$ are shown. Capnocytophaga ochracea ATCC $33596^{\top}$ was used as an outgroup. Bar, 0.01 changes per nucleotide position. 
enzymic activities and biochemical features were determined using API ZYM and API $20 \mathrm{E}$ kits at $30^{\circ} \mathrm{C}$ as recommended by the manufacturer (bioMérieux).

Growth of strain EMB47 ${ }^{\mathrm{T}}$ was observed at temperatures between 10 and $45^{\circ} \mathrm{C}$, the optimum being at $25-35^{\circ} \mathrm{C}$. The strain grew at $\mathrm{pH}$ values in the range $5 \cdot 5-8 \cdot 5$, the optimum being $\mathrm{pH} 7 \cdot 5-8 \cdot 0$. The cells were Gram-negative, straight or slightly curved rods $0 \cdot 3-0 \cdot 5 \mu \mathrm{m}$ in width and $1 \cdot 0-3 \cdot 2 \mu \mathrm{m}$ in length (see Supplementary Fig. S1 available in IJSEM Online). The isolate grew optimally on R2A medium without the addition of $\mathrm{NaCl}$, and growth was severely inhibited on R2A medium containing more than $1 \%(\mathrm{w} / \mathrm{v})$ $\mathrm{NaCl}$. Other phenotypic features of strain $\mathrm{EMB} 47^{\mathrm{T}}$ are presented in Table 1 and in the description of the novel species. Some of the characteristics are in accordance with those of members of the genus Flavobacterium, whereas others allow the differentiation of strain $\mathrm{EMB} 47^{\mathrm{T}}$ from closely related Flavobacterium species (Table 1).

Analysis of the fatty acid methyl esters was performed according to the instructions of the Microbial Identification System (MIDI; Microbial ID). Analyses of the polar lipids and isoprenoid quinones were carried out using the methods described by Komagata \& Suzuki (1987). The

Table 1. Characteristics of strain EMB $47^{\top}$ and related Flavobacterium species

Taxa: 1, strain $\mathrm{EMB}^{\mathrm{T}}{ }^{\mathrm{T}}$; 2, F. aquatile (Bernardet et al., 1996); 3 , F. columnare (Tamaki et al., 2003); 4, F. saliperosum AS $1.3801^{\mathrm{T}}$ (Wang et al., 2006); 5, Flavobacterium psychrophilum (Bernardet et al., 1996; Tamaki et al., 2003). +, Positive; -, negative; v, variable among strains; V, variable among references; $(+)$, weakly positive; NA, not available. All strains could degrade casein but not carboxymethylcellulose.

\begin{tabular}{|lccccc|}
\hline Characteristic & $\mathbf{1}$ & $\mathbf{2}$ & $\mathbf{3}$ & $\mathbf{4}$ & $\mathbf{5}$ \\
\hline Growth on: & & & & & \\
$\quad$ Nutrient agar & - & - & - & + & - \\
Trypticase soy agar & $(+)$ & $(+)$ & - & $(+)$ & - \\
Growth at $25^{\circ} \mathrm{C}$ & + & + & + & + & - \\
Gliding motility & - & + & + & - & $(+)$ \\
Flexirubin-type pigments & - & - & + & + & + \\
Acid from glucose & + & + & - & - & - \\
Congo red adsorption & - & - & + & - & - \\
Degradation of: & & & & & \\
$\quad$ Gelatin & + & $\mathrm{V}$ & + & + & + \\
$\quad$ Starch & - & $\mathrm{V}$ & - & - & - \\
$\quad$ Aesculin & - & $\mathrm{V}$ & - & - & - \\
$\quad$ Tyrosine & - & $\mathrm{V}$ & - & - & $\mathrm{v}$ \\
Brown pigment on tyrosine agar & - & - & $\mathrm{v}$ & + & - \\
$\mathrm{H}_{2} \mathrm{~S}$ production & - & - & + & - & - \\
$\beta$-Galactosidase activity & - & $\mathrm{V}$ & - & $\mathrm{NA}$ & - \\
Nitrate reduction & - & $\mathrm{V}$ & $\mathrm{V}$ & - & - \\
DNA G+C content (mol\%) & $40 \cdot 8$ & 33 & 32 & 41 & 33 \\
& & & & & \\
\hline
\end{tabular}

DNA G + C content of strain EMB $47^{\mathrm{T}}$ was determined using HPLC with a reversed-phase column (GROM-SIL 100 ODS2FE; GROM) according to the method of Tamaoka \& Komagata (1984). The major respiratory lipoquinone of strain $\mathrm{EMB} 47^{\mathrm{T}}$ was MK-6. The cellular membrane of the strain contained iso- $\mathrm{C}_{16: 0} 3-\mathrm{OH}(16 \cdot 5 \%)$, iso- $\mathrm{C}_{15: 1}$ $\mathrm{G}(11 \cdot 5 \%), \mathrm{C}_{15: 0}(10 \cdot 8 \%)$, iso- $\mathrm{C}_{15: 0}(9 \cdot 3 \%)$, iso- $\mathrm{C}_{14: 0}$ $(8 \cdot 7 \%)$ and iso- $\mathrm{C}_{16: 0}(8 \cdot 5 \%)$ as the major fatty acids, a profile resembling those determined for Flavobacterium species (Bernardet et al., 2002; Wang et al., 2006; Yoon et al., 2006). The predominant polar lipid of strain EMB $47^{\mathrm{T}}$ was phosphatidylethanolamine, and small amounts of phosphatidylglycerol and phosphatidylcholine were also present. The $\mathrm{G}+\mathrm{C}$ content of the genomic DNA of strain $\mathrm{EMB} 47^{\mathrm{T}}$ was $40 \cdot 8 \mathrm{~mol} \%$. The fatty acid composition, major lipoquinone, major polar lipid and $\mathrm{G}+\mathrm{C}$ content are in accordance with those of members of the genus Flavobacterium (Bernardet et al., 2002; Van Trappen et al., 2004, 2005; Aslam et al., 2005; Wang et al., 2006; Yoon et al., 2006). Therefore, the physiological, biochemical and phylogenetic data for strain EMB47 ${ }^{\mathrm{T}}$ support its description as a novel species within the genus Flavobacterium, for which the name Flavobacterium croceum sp. nov. is proposed.

\section{Description of Flavobacterium croceum sp. nov.}

Flavobacterium croceum (cro'ce.um. L. neut. adj. croceum yellow).

Cells form yellow, slightly raised, circular colonies with entire margins on R2A agar. Growth occurs optimally at $25-35^{\circ} \mathrm{C}$ and $\mathrm{pH} 7 \cdot 5-8 \cdot 0$. Cells are Gram-negative, nonmotile rods $0 \cdot 3-0 \cdot 5 \mu \mathrm{m}$ wide and $1 \cdot 0-3 \cdot 2 \mu \mathrm{m}$ long at $30^{\circ} \mathrm{C}$ on R2A agar. Nitrate is not reduced to nitrite. Anaerobic growth is not observed at 7 days at $30{ }^{\circ} \mathrm{C}$ on $\mathrm{R} 2 \mathrm{~A}$ agar, but weak growth occurs after 16 days. Catalase-negative and oxidase-positive. $\mathrm{NaCl}$ concentrations above $1 \%$ severely inhibit growth. Casein and gelatin are hydrolysed. Hypoxanthine, Tweens 80 and 20, aesculin, urea, tyrosine, starch, carboxymethylcellulose and xanthine are not hydrolysed. Congo red is not absorbed by colonies and flexirubin-type pigments are not produced. Negative for indole, $\mathrm{H}_{2} \mathrm{~S}$ and acetoin production and for citrate utilization (API 20E kit). Produces acid from raffinose, Dglucose, myo-inositol, lactose, L-arabinose and melibiose, but not from D-fructose, D-galactose, D-mannose, Dmannitol, arbutin or salicin. Produces alkaline phosphatase and leucine arylamidase, but not esterase (C4), esterase lipase (C8), lipase (C14), cystine arylamidase, $\alpha$-chymotrypsin, $\alpha$-galactosidase, $\beta$-galactosidase, $\beta$-glucuronidase, $\alpha$-glucosidase, $\beta$-glucosidase, $N$-acetyl- $\beta$-glucosaminidase, $\alpha$-mannosidase, $\alpha$-fucosidase, arginine dihydrolase, lysine decarboxylase, ornithine decarboxylase or urease. Weak enzymic activities are observed for valine arylamidase, trypsin, acid phosphatase, naphthol-AS-BI-phosphohydrolase and tryptophan deaminase. Strain EMB $47^{\mathrm{T}}$ is resistant to polymyxin $\mathrm{B}$, gentamicin, kanamycin, oleandomycin and neomycin and is sensitive to ampicillin, streptomycin, penicillin G, chloramphenicol, tetracycline, lincomycin, 
carbenicillin and novobiocin. The strain contains a large amount of phosphatidylethanolamine and small amounts of phosphatidylglycerol and phosphatidylcholine as the polar lipids. The major isoprenoid quinone is MK-6. The cellular fatty acids are iso- $\mathrm{C}_{16: 0} 3-\mathrm{OH}(16 \cdot 5 \%)$, iso- $\mathrm{C}_{15: 1} \mathrm{G}$ $(11 \cdot 5 \%), \mathrm{C}_{15: 0}(10 \cdot 8 \%)$, iso- $\mathrm{C}_{15: 0}(9 \cdot 3 \%)$, iso- $\mathrm{C}_{14: 0}$ $(8 \cdot 7 \%)$, iso- $\mathrm{C}_{16: 0}(8 \cdot 5 \%)$, iso- $\mathrm{C}_{15: 0} 3-\mathrm{OH}(5 \cdot 9 \%)$, anteiso- $\mathrm{C}_{15: 0}(5 \cdot 1 \%)$, iso- $\mathrm{C}_{16: 1} \mathrm{G}(2 \cdot 9 \%)$, iso- $\mathrm{C}_{17: 0} 3-\mathrm{OH}$ $(2 \cdot 7 \%)$, iso- $\mathrm{C}_{14: 0} 3-\mathrm{OH}(2 \cdot 6 \%), \mathrm{C}_{15: 0} 2-\mathrm{OH}(2 \cdot 0 \%)$, anteiso- $\mathrm{C}_{15: 1} \mathrm{~A}(1 \cdot 6 \%), \mathrm{C}_{15: 0} 3-\mathrm{OH}(1 \cdot 3 \%), \mathrm{C}_{16: 0}(1 \cdot 0 \%)$, iso- $\mathrm{C}_{13: 0}(1 \cdot 0 \%), \mathrm{C}_{16: 0} 3-\mathrm{OH}(0 \cdot 6 \%)$, iso- $\mathrm{C}_{12: 0}(0 \cdot 5 \%)$, anteiso- $\mathrm{C}_{13: 0}(0 \cdot 5 \%), \mathrm{C}_{17: 0} 3-\mathrm{OH}(0 \cdot 5 \%)$ and summed feature $3\left(\mathrm{C}_{16: 1} \omega 7 c\right.$ and/or iso- $\left.\mathrm{C}_{15: 0} 2-\mathrm{OH}, 3 \cdot 6 \%\right)$. DNA $\mathrm{G}+\mathrm{C}$ content is $40 \cdot 8 \mathrm{~mol} \%$ (HPLC).

The type strain, $\mathrm{EMB}_{4} 7^{\mathrm{T}}\left(=\mathrm{KCTC} 12611^{\mathrm{T}}=\mathrm{DSM} 17960^{\mathrm{T}}\right)$, was isolated from sludge that performed enhanced biological phosphorus removal in a laboratory-scale sequencing batch reactor.

\section{Acknowledgements}

This work was supported by grants from MOST/KOSEF to the Environmental Biotechnology National Core Research Center (grant R15-2003-012-02002-0) and to the 21C Frontier Microbial Genomics and Application Center Program (grant MG05-0104-4-0), Ministry of Science and Technology, Korea. M. P. and S. L. were supported by scholarships from the BK21 program, the Ministry of Education and Human Resources Development in Korea.

\section{References}

Aslam, Z., Im, W. T., Kim, M. K. \& Lee, S. T. (2005). Flavobacterium granuli sp. nov., isolated from granules used in a wastewater treatment plant. Int J Syst Evol Microbiol 55, 747-751.

Bernardet, J.-F., Segers, P., Vancanneyt, M., Berthe, F., Kersters, K. \& Vandamme, P. (1996). Cutting a Gordian knot: emended classification and description of the genus Flavobacterium, emended description of the family Flavobacteriaceae, and proposal of Flavobacterium hydatis nom. nov. (basonym, Cytophaga aquatilis Strohl and Tait 1978). Int J Syst Bacteriol 46, 128-148.

Bernardet, J. F., Nakagawa, Y. \& Holmes, B. (2002). Proposed minimal standards for describing new taxa of the family Flavobacteriaceae and emended description of the family. Int J Syst Evol Microbiol 52, 1049-1070.

Cole, J. R., Chai, B., Marsh, T. L. \& 8 other authors (2003). The ribosomal database project (RDP-II): previewing a new autoaligner that allows regular updates and the new prokaryotic taxonomy. Nucleic Acids Res 31, 442-443.

Felsenstein, J. (2002). PHYLIP (phylogeny inference package), version 3.6a. Distributed by the author. Department of Genome Sciences, University of Washington, Seattle, USA.

Gerhardt, P., Murray, R. G. M., Wood, W. A. \& Krieg, N. R. (1994). Phenotypic characterization. In Methods for General and Molecular Bacteriology, pp. 607-654. Edited by P. Gerhardt. Washington, DC: American Society for Microbiology.

Gomori, G. (1955). Preparation of buffers for use in enzyme studies. Methods Enzymol 1, 138-146.

Horn, M. A., Ihssen, J., Matthies, C., Schramm, A., Acker, G. \& Drake, H. L. (2005). Dechloromonas denitrificans sp. nov., Flavobacterium denitrificans sp. nov., Paenibacillus anaericanus sp. nov. and Paenibacillus terrae strain $\mathrm{MH} 72, \mathrm{~N}_{2} \mathrm{O}$-producing bacteria isolated from the gut of the earthworm Aporrectodea caliginosa. Int J Syst Evol Microbiol 55, 1255-1265.

Humphry, D. R., George, A., Black, G. W. \& Cummings, S. P. (2001). Flavobacterium frigidarium sp. nov., an aerobic, psychrophilic, xylanolytic and laminarinolytic bacterium from Antarctica. Int J Syst Evol Microbiol 51, 1235-1243.

Jeon, C. O. \& Park, J. M. (2000). Enhanced biological phosphorus removal in a sequencing batch reactor supplied with glucose as a sole carbon source. Water Res 34, 3470-3480.

Jeon, C. O., Lee, D. S. \& Park, J. M. (2003). Microbial communities in activated sludge performing enhanced biological phosphorus removal in a sequencing batch reactor. Water Res 37, 2195-2205.

Jeon, C. O., Lim, J. M., Lee, J. M., Xu, L. H., Jiang, C. L. \& Kim, C. J. (2005). Reclassification of Bacillus haloalkaliphilus Fritze 1996 as Alkalibacillus haloalkaliphilus gen. nov., comb. nov. and the description of Alkalibacillus salilacus sp. nov., a novel halophilic bacterium isolated from a salt lake in China. Int J Syst Evol Microbiol 55, 743-746.

Kimura, M. (1980). A simple method for estimating evolutionary rates of base substitutions through comparative studies of nucleotide sequences. J Mol Evol 16, 111-120.

Komagata, K. \& Suzuki, K. (1987). Lipid and cell-wall analysis in bacterial systematics. Methods Microbiol 19, 161-208.

Lane, D. J. (1991). 16S/23S rRNA sequencing. In Nucleic Acid Techniques in Bacterial Systematics, pp. 115-175. Edited by E. Stackebrandt \& M. Goodfellow. Chichester, UK: Wiley.

Lanyi, B. (1987). Classical and rapid identification methods for medically important bacteria. Methods Microbiol 19, 1-67.

Leifson, E. (1963). Determination of carbohydrate metabolism of marine bacteria. J Bacteriol 85, 1183-1184.

McCammon, S. A. \& Bowman, J. P. (2000). Taxonomy of Antarctic Flavobacterium species: description of Flavobacterium gillisiae sp. nov., Flavobacterium tegetincola sp. nov., and Flavobacterium xanthum sp. nov., nom. rev. and reclassification of [Flavobacterium] salegens as Salegentibacter salegens gen. nov., comb. nov. Int J Syst Evol Microbiol 50, 1055-1063.

Mino, T., Arun, V., Suzuki, Y. T. \& Matsuo, T. (1987). Effect of phosphorus accumulation on acetate metabolism in the biological phosphorus removal process. In Biological Phosphate Removal from Wastewaters, pp. 27-38. Edited by R. Ramadori. Oxford, UK: Pergamon Press.

Tamaki, H., Hanada, S., Kamagata, Y., Nakamura, K., Nomura, N., Nakano, K. \& Matsumura, M. (2003). Flavobacterium limicola sp. nov., a psychrophilic, organic-polymer-degrading bacterium isolated from freshwater sediments. Int J Syst Evol Microbiol 53, 519-526.

Tamaoka, J. \& Komagata, K. (1984). Determination of DNA base composition by reverse-phase high-performance liquid chromatography. FEMS Microbiol Lett 25, 125-128.

Thompson, J. D., Higgins, D. G. \& Gibson, T. J. (1994). CLUSTAL W: improving the sensitivity of progressive multiple sequence alignment through sequence weighting, position-specific gap penalties and weight matrix choice. Nucleic Acids Res 22, 4673-4680.

Van Trappen, S., Mergaert, J., Van Eygen, S., Dawyndt, P., Cnockaert, M. C. \& Swings, J. (2002). Diversity of 746 heterotrophic bacteria isolated from microbial mats from ten Antarctic lakes. Syst Appl Microbiol 25, 603-610.

Van Trappen, S., Vandecandelaere, I., Mergaert, J. \& Swings, J. (2004). Flavobacterium degerlachei sp. nov., Flavobacterium frigoris sp. nov. and Flavobacterium micromati sp. nov., novel psychrophilic bacteria isolated from microbial mats in Antarctic lakes. Int J Syst Evol Microbiol 54, 85-92. 
Van Trappen, S., Vandecandelaere, I., Mergaert, J. \& Swings, J. (2005). Flavobacterium fryxellicola sp. nov. and Flavobacterium psychrolimnae sp. nov., novel psychrophilic bacteria isolated from microbial mats in Antarctic lakes. Int J Syst Evol Microbiol 55, 769-772.

Wang, Z.-W., Liu, Y.-H., Dai, X., Wang, B.-J., Jiang, C.-Y. \& Liu, S.-J. (2006). Flavobacterium saliperosum sp. nov., isolated from freshwater lake sediment. Int J Syst Evol Microbiol 56, 439-442.
Yoon, J.-H., Kang, S.-J. \& Oh, T.-K. (2006). Flavobacterium soli sp. nov., isolated from soil. Int $J$ Syst Evol Microbiol 56, 997-1000.

Zhu, F., Wang, S. \& Zhou, P. (2003). Flavobacterium xinjiangense sp. nov. and Flavobacterium omnivorum sp. nov., novel psychrophiles from the China No. 1 glacier. Int J Syst Evol Microbiol 53, 853-857. 